\title{
First record of the brown mussel (Perna perna) from the European Atlantic coast
}

\author{
CARLA R. LOURENÇO, KATY R. NICASTRO, ESTER A. SERRÃO AND GERARDO I. ZARDI \\ CCMAR-CIMAR-Laboratório Associado, Universidade do Algarve, Gambelas, 8005-139, Faro, Portugal
}

\begin{abstract}
The occurrence of the brown mussel Perna perna is reported for the first time from the European Atlantic coast, on the southern Portuguese coast. Several specimens of this mytilidae species were identified in exposed rocky intertidal habitats in Vilamoura $\left(37^{\circ} 04^{\prime} 19.70^{\prime \prime} \mathrm{N} 8^{\circ} 07^{\prime} 19.71^{\prime \prime} W\right)$ and Ilha do Farol $\left(36^{\circ} 58^{\prime} 29.38^{\prime \prime} N 7^{\circ} 51^{\prime} 42.51^{\prime \prime} W\right)$. It is suggested that, under warming climate conditions, this subtropical/tropical species might have extended its geographical distribution from North Africa.
\end{abstract}

Keywords: brown mussel, Perna perna, Portugal, European Atlantic coast, range expansion

Submitted 27 February 2012; accepted 1 March 2012

\section{INTRDDUCTION}

The brown mussel Perna perna (Linnaeus, 1785) is a subtropical/tropical species that is widely distributed along Madagascar, the east African coast (from central Mozambique to False Bay), the west coast of Africa (from Luderiz Bay north into the Mediterranean) and from the Strait of Gibraltar (African side) to the Gulf of Tunis (Berry, 1978). It is also present in Sri Lanka, southern India and on the Atlantic coast of South America where it was reported in Venezuela, Uruguay, and Brazil as well as in the West Indies (Berry, 1978; Vakily, 1989; Wood et al., 2007). In Brazil, $P$. perna has been reclassified as an old introduction, most likely dating from the 16th Century (Silva \& Barros, 2011).

In the United States, P. perna invaded Texas (Gulf of Mexico) shores in 1990 (Hicks \& Tunnell, 1993). This mussel species is thought to have been introduced to this area via ballast water release (Hicks \& Tunnel, 1993), and its invasion has attracted much attention because of its potential threat to shipping safety and to cooling water systems of coastal power stations (Hicks \& McMahon, 2002; Rajagopal et al., 2003). Perna perna has recently been detected on an oil rig in New Zealand waters but vigorous efforts by the Biosecurity New Zealand system strongly reduced the likelihood of a successful population establishment (Manawatu Standard, 2008).

Perna perna has never been observed along the European Atlantic coast, despite several extensive surveys of intertidal communities having been conducted since the mid-1950s (e.g. Fischer-Piétte, 1958, 1963; Santos, 2000; Boaventura et al., 2002; Fa et al., 2003; Arauújo et al., 2005; Guerra-García et al., 2006; Lima et al., 2006, 2007; Pereira et al., 2006).

Corresponding author:

C.R. Lourenço

Email: carla.rodrigues.lourenco@gmail.com

\section{MATERIALS AND METHODS}

\section{Study area and sampling}

Extensive field surveys were carried out during low spring tides between April and November 2011 on rocky intertidal shores along the southern Portuguese coast, from Vilamoura $\left(37^{\circ} 04^{\prime} 19.70^{\prime \prime} \mathrm{N} \quad 8^{\circ} 07^{\prime} 19.71^{\prime \prime} \mathrm{W}\right)$ to Tavira ( $37^{\circ} 06^{\prime} 58.48^{\prime \prime} \mathrm{N}$ $7^{\circ} 37^{\prime} 43 \cdot 86^{\prime \prime} \mathrm{W}$ ). All locations were visited at least twice (covering winter and summer months) and each location included two sites from $500 \mathrm{~m}$ to $1 \mathrm{~km}$ apart. At each site, two observers performed approximately 60 minutes searches across all microhabitats present.

\section{Identification}

Key morphological and behavioural characters were used to identify Perna perna specimens (Siddal, 1980; Vakily, 1989; Nicastro et al., 2010). A main diagnostic feature is the pattern of the scars left at the area of muscle attachment on shells. In Mytilus spp., the scar left by the posterior adductor and retractor muscles is united forming a continuous band along the dorsal margin of the pallial line (Siddal, 1980). In contrast, these two muscles attach separately on the shell in Perna spp., resulting in a discontinuous scar (Figure 1). Another key character is the anterior adductor muscle which is present although small, in Mytilus spp. but absent in all Perna spp. (Siddal, 1980). Moreover, the shell of $P$. perna adults presents a brown to red-maroon colour with some irregular light brown and green areas (Siddal, 1980). Despite mussel shell plasticity, the width (the maximum distance along the lateral axis between the two valves of the closed shell) and the height (the maximum distance along the dorso-ventral axis across the mid-axis of the shell) can also be used to identify $P$. perna specimens (shells are typically higher than wider: Marques et al., 1998).

Finally, gaping (periodic valve movement during emersion) is an ideal diagnostic behavioural trait to distinguish between Mytilus galloprovincialis and P. perna individuals. During 


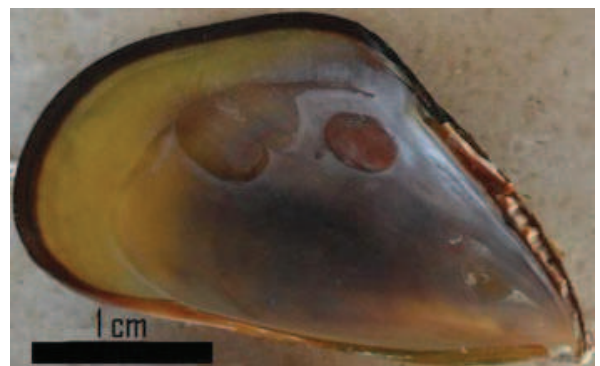

Fig. 1. Left valve of a Perna perna specimen: the characteristic posterior double scar is shown.

emergence, intertidal mussels either keep the valves closed, minimizing water loss and utilizing anaerobic metabolism (non-gaping species), or periodically open the valves allowing more efficient aerobic metabolism but increasing the risk of desiccation (gaping species: Widdows et al., 1979; Famme \& Kofoed, 1980). In contrast to the non-gaping M. galloprovincialis, P. perna is a gaping species (Nicastro et al., 2010).

\section{RESULTS AND DISCUSSION}

Several individuals of Perna perna were first observed in Vilamoura $\left(37^{\circ} 04^{\prime} 19.70^{\prime \prime} \mathrm{N} 8^{\circ} 07^{\prime} 19.71^{\prime \prime} \mathrm{W}\right)$ and Ilha do Farol $\left(36^{\circ} 58^{\prime} 29.38^{\prime \prime} \mathrm{N} 7^{\circ} 51^{\prime} 42.51^{\prime \prime} \mathrm{W}\right)$, south coast of Portugal on 1 and 3 July 2011, and their presence was followed during the consecutive months. Perna perna was interspersed within beds of the dominant mussel species Mytilus galloprovincialis in the lower eulittoral zone (hereafter referred to as the mussel zone; Figure 2).

All key features such as the light-brown colour, the double posterior muscle scar, the absence of an anterior adductor muscle and the gaping behaviour confirmed that all individuals belong to $P$. perna species. Furthermore, $P$. perna specimens were higher than wider as previously described by Marques et al. (1998), on average 2.4 and $1.7 \mathrm{~mm}$ for height and width respectively.

Perna perna and M. galloprovincialis overlap in their distributions on the Atlantic coast of North Africa and the Mediterranean coast of Algeria (Abada-Boudjema \& Dauvin, 1995). In these regions, the two species co-occur in high abundance and have reached a distributional equilibrium through partial habitat segregation (Bownes \& McQuaid, 2006). The upper and the lower areas of the mussel zone are dominated by M. galloprovincialis and P. perna respectively,

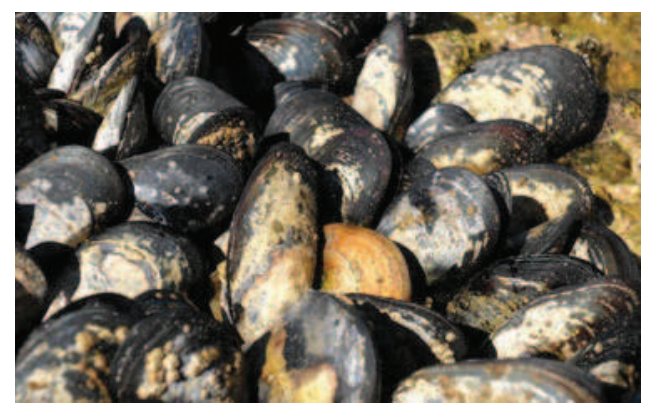

Fig. 2. Isolated brown mussel (Perna perna) in the centre of a blue mussel bed (Mytilus galloprovincialis) from Vilamoura on 1 July 2011. while the two species overlap in the mid-mussel zone. Moreover, M. galloprovincialis shows similar patterns of zone segregation with Perna viridis in Hong Kong (Lee \& Morton, 1985) and Perna canaliculus in New Zealand (McDonald et al., 1991). Previous studies showed that partial habitat segregation of these two species results from a combination of biotic and physical conditions along a gradient of multiple stresses (e.g. Zardi et al., 2006; Rius \& McQuaid, 2009; Nicastro et al., 2010). In contrast, the mussel zone in southern Portugal is characterized by a lack of vertical segregation with few $P$. perna individuals sparingly distributed within the dominating $M$. galloprovincialis. Low population density and lower habitat occupancy is typical of marginal populations, which exist at the ecological edges of a species range living under unfavourable ecological conditions (Sagarin et al., 2006). A continuous monitoring of the structure and dynamics of mixed populations of the two mussel species will be important to define the impact of $P$. perna and to understand if the distribution of these coexisting species is stable or if it will evolve to the same vertical patterns observed in other regions.

The presence of $P$. perna on the Portuguese southern coast is a striking shift of the previous northern distributional boundary along the Moroccan coastline (Siddal, 1980; Vakily, 1989; Wood et al., 2007). Perna perna has larvae with a long pelagic stage that, under favourable conditions, can disperse over large distances $(100 \mathrm{~km})$ before settling (McQuaid \& Phillips, 2000). Such a large dispersal potential could have allowed dispersal from North African populations and colonization of European shores. Over the last 50 years, sea surface temperatures along the Portuguese coast have consistently increased (Lima et al., 2007). The range expansion of the subtropical/tropical species $P$. perna is consistent with general predictions of species distributional shifts under warming climate scenarios, which anticipate northwards expansions of warm-water taxa (Parmesan \& Yohe, 2003; Helmuth et al., 2006; Mieszkowska et al., 2007; Hawkins et al., 2009). Genetic characterization is needed to determine the exact origin of $P$. perna Portuguese populations and also to understand if multiple introductions have occurred over time.

Intertidal mussels are fascinating models for studies of climate-induced range shifts over small (intertidal) and large (latitudinal) spatial scales (Harley, 2011). Perna perna, together with other key species, whose distributional ranges are changing along the Portuguese coastline (e.g. Fucus spp.: Viejo et al., 2011) is an ideal model organism to study climatic-driven biogeographical changes.

\section{ACKNOWLEDGEMENTS}

We are grateful to Rúben Silva for field assistance. This research was supported by post-doctoral fellowships from FCT, Portugal (to G.I.Z. and K.R.N.) and funded by project PTDC/BIA-BEC/103916/2008 from FCT (to G.I.Z.).

\section{REFERENCES}

Abada-Boudjema Y-M. and Davin J-C. (1995) Recruitment and life span of two natural mussel populations Perna perna (Linnaeus) and Mytilus 
galloprovincialis (Lamarck) from the Algerian coast. Journal of Molluscan Studies 61, 467-481.

Araújo R., Bárbara I., Sousa-Pinto I. and Quintino V. (2005) Spatial variability of intertidal rocky shore assemblages in the northwest coast of Portugal. Estuarine, Coastal and Shelf Science 64, 658-670.

Berry P.F. (1978) Reproduction, growth and production in the mussel, Perna perna (Linnaeus), on the east coast of South Africa. The Oceanographic Research Institute, Durban (Investigational Report No. 48 ).

Boaventura D., Ré P., Fonseca L. and Hawkins S.J. (2002) Intertidal rocky shore communities of the continental Portuguese coast: analysis of distribution patterns. Marine Ecology 23, 69-90.

Bownes S. and McQuaid C.D. (2006) Will the invasive mussel Mytilus galloprovincialis Lamarck replace the indigenous Perna perna L. on the south coast of South Africa? Journal of Experimental Marine Biology and Ecology 338, 140-151.

Fa D.A., Sánchez-Moyano J.E., García-Asencio I., García-Gómez J.C., Finlayson C. and Sheader M. (2003) A comparative study of the marine ecoregions of the southern Iberian Peninsula, as identified from different coastal habitats. Boletin del Instituto Español de Oceanografia 19, 135-147.

Famme P. and Kofoed L.H. (1980) The ventilatory current and ctenidial function related to oxygen in declining oxygen tension by the mussel Mytilus edulis L. Comparative Biochemistry and Physiology Part A: Physiology 66, 161-171.

Fischer-Piétte E. (1958) Sur l'écologie intercotidal ouest-ibérique. Comptes Rendus de l'Académie des Sciences (Paris) 246, 1301-1303.

Fischer-Piétte E. (1963) La distribution des principaux organisms nord-ibériques en 1954-55. Annales de l'Institut Océanographique, Paris 40, 165-311.

Guerra-García J.M., Maestre M.J., González A.R. and García-Gómez J.C. (2006) Assessing a quick monitoring method using rocky intertidal communities as a bioindicator: a multivariate approach in Algeciras Bay. Environmental Monitoring and Assessment 116, 345361.

Harley C. (2011) Climate change, keystone predation, and biodiversity loss. Science 334, 1124-1127.

Hawkins S.J., Sugden H.E., Mieszkowska N., Moore P.J., Poloczanska E., Leaper R., Herbert R.J.H., Genner M.J., Moschella P.S., Thompson R.C., Jenkins S.R., Southward A.J. and Burrows M.T. (2009) Consequences of climate-driven biodiversity changes for ecosystem functioning of North European rocky shores. Marine Ecology Progress Series 396, 245-259.

Helmuth B., Mieszkowska N., Moore P. and Hawkins S.J. (2006) Living on the edge of two changing worlds: forecasting the responses of rocky intertidal ecosystems to climate change. Annual Review of Ecology, Evolution, and Systematics 37, 373-404.

Hicks D.W. and MacMahon R.F. (2002) Temperature acclimation of upper and lower thermal limits and freeze resistance in the nonindigenous brown mussel, Perna perna (L.), from the Gulf of Mexico. Marine Biology 140, 1167-1179.

Hicks D.W. and Tunnell J.W. Jr (1993) Invasion of the south Texas coast by the edible brown mussel Perna perna (Linnaeus, 1758). Veliger 36, $92-99$.

Lee S.Y. and Morton B.S. (1985) The introduction of the Mediterranean mussel Mytilus galloprovincialis into Hong Kong. Malacological Review 18, 107-109.

Lima F.P., Queiroz N., Ribeiro P.A., Hawkins S.J. and Santos A.M. (2006) Recent changes in the distribution of a marine gastropod, Patella rustica Linnaeus, 1758 , and their relationship to unusual climatic events. Journal of Biogeography 33, 812-822.
Lima F.P., Ribeiro P.A., Queiroz N., Hawkins S.J. and Santos A.M. (2007) Do distributional shifts of northern and southern species of algae match the warming pattern? Global Change Biology 13, 25922604.

Manawatu Standard (2008) Mussel Scare Has Industry on Edge. 28 February, 2008. http://www.stuff.co.nz/291759/Mussel-scare-hasindustry-on-edge (accessed 25 February 2012).

Marques H., Pereira R. and Correa B. (1998) Seasonal variation in growth and yield of the brown mussel Perna perna (L.) cultured in Ubatuba, Brazil. Aquaculture 169, 263-273.

McDonald J.H., Seed R. and Koehn R.K. (1991) Allozymes and morphometric characters of three species of Mytilus in the Northern and Southern Hemispheres. Marine Biology 111, 323-333.

McQuaid C.D. and Phillips T.E. (2000) Limited wind-driven dispersal of intertidal mussel larvae: in situ evidence from the plankton and the spread of the invasive species Mytilus galloprovincialis in South Africa. Marine Ecology Progress Series 201, 211-220.

Mieszkowska N., Hawkins S.J., Burrows M.T. and Kendall M.A. (2007) Long-term changes in the geographic distribution and population structures of Osilinus lineatus (Gastropoda: Trochidae) in Britain and Ireland. Journal of the Marine Biological Association of the United Kingdom 87, 537-545.

Nicastro K.R., Zardi G.I., McQuaid C.D., Stephens L., Radloff S. and Blatch G.L. (2010) The role of gaping behaviour in habitat partitioning between coexisting intertidal mussels. BMC Ecology 10, 1-11.

Parmesan C. and Yohe G. (2003) A globally coherent fingerprint of climate change impacts across natural systems. Nature 421, 37-42.

Pereira S.G., Lima F.P., Queiroz N.C., Ribeiro P.A. and Santos A.M. (2006) Biogeographic patterns of intertidal macroinvertebrates and their association with macroalgae distribution along the Portuguese coast. Hydrobiologia 555, 185-192.

Rajagopal S., Venugopalan V.P., Van der Velde G. and Jenner H.A. (2003) Tolerance of five species of tropical marine mussels to continuous chlorination. Marine Environmental Research 55, 277-291.

Rius M. and McQuaid C.D. (2009) Facilitation and competition between invasive and indigenous mussels over a gradient of physical stress. Basic and Applied Ecology 10, 607-613.

Sagarin R.D., Gaines S.D. and Gaylord B. (2006) Moving beyond assumptions to understand abundance distributions across the ranges of species. Trends in Ecology and Evolution 21, 524-530.

Santos A.M. (2000) Intertidal ecology of northern Portuguese rocky shores. $\mathrm{PhD}$ thesis. School of Biological Sciences, University of Southampton, UK.

Siddal S.E. (1980) A clarification of the genus Perna (Mytilidae). Bulletin of Marine Science 30, 858-870.

Silva E.C. and Barros F. (2011) Macrofauna bentónica introduzida no Brasil: lista de espécies marinhas e dulcícolas e distribuição atual. Oecologia Australis 15, 326-344.

Vakily J.M. (1989) The biology and culture of mussels of the genus Perna. ICLARM Studies and Reviews. International Center for Living Aquatic Resources Management, Manilla, Philippines, no. 17, 63 pp.

Viejo R., Martínez B., Arrontes J., Astudillo C. and Hernández L. (2011) Reproductive patterns in central and marginal populations of a large brown seaweed: drastic changes at the southern range limit. Ecography 34, 75-84.

Widdows J., Bayne B.L., Livingstone D.R., Newell R.I.E. and Donkin P. (1979) Physiological and biochemical responses of bivalve molluscs to exposure in air. Comparative Biochemistry and Physiology Part A: Physiology 62, 301-308. 
Wood A.R., Apte S., MacAvoy E.S. and Gardner J. (2007) A molecular phylogeny of the marine mussel genus Perna (Bivalvia: Mytilidae) based on nuclear (ITS 1 \&2) and mitochondrial (COI) DNA sequences. Molecular Phylogenetics and Evolution 44, 685-698.

and

Zardi G.I., Nicastro K.R., McQuaid C.D., Rius M. and Porri F. (2006) Hydrodynamic stress and habitat partitioning between indigenous
(Perna perna) and invasive (Mytilus galloprovincialis) mussels: constraints of an evolutionary strategy. Marine Biology 150, 78-88.

\section{Correspondence should be addressed to:}

C.R. Lourenço

CCMAR - CIMAR-Laboratório Associado

Universidade do Algarve, Gambelas, 8005-139, Faro, Portugal email: carla.rodrigues.lourenco@gmail.com 